\title{
XII. On the chemical composition of white efflorescent pyrites
}

\section{M.J. Berzelius}

To cite this article: M.J. Berzelius (1822) XII. On the chemical composition of white efflorescent pyrites, Philosophical Magazine Series 1, 60:291, 65-66, DOI: 10.1080/14786442208652790

To link to this article: http://dx.doi.org/10.1080/14786442208652790

曲 Published online: 29 Jul 2009.

Submit your article to this journal ๘

Џll Article views: 2

Q View related articles $\square$ 
XII. On the Chemical Composition of white efflorescent Pyrites. By $M$. J. Berzelius *.

$\mathbf{I}_{\mathbf{T}}$ is well known that the crystalline form of white pyrites differs so essentially from that of yellow pyrites, that M. Haiuy thought he ought to class them as two different mineral species. No difference in the composition of the two substances, however, can be discovered by chemical analysis; which adds one more to the exceptions to the general rule, furnished by the diversity in the two forms of carbonated lime, and that more recently observed by M. Mitscherlich in two forms of the surphosphate of soda.

White pyrites consists of two varieties; one of which, perfectly crystallized, stands the air; while the other, which presents a confused crystallization, effloresces on exposure to the air, and falls into a powder evidently vitriolic. This phænomenon proves, then, a difference of composition between the two varieties; a difference which deserves to be studied, in order that we may see whether it can explain the difference between them and yellow pyrites.

I allowed a piece of white pyrites to effloresce for two years and a half; and when it was entirely reduced I subjected it to examination. Its bulk was almost doubled; and it fell into pieces on the slightest touch. A part of the mass was converted into a white powder, of a styptic taste, and this powder had begun to grow yellowish towards the edges. Viewed through a microscope it presented a mass full of small cavities filled with a white and effloresced salt, the interstices between which appeared to be of white pyrites in an entire state, and more or less crystalline.

I then tried a portion of it with water; and separated the dissolved part from the indissoluble residue. The latter consisted partly of a rough powder, which was composed of small crystals of pyrites, and partly of a powder finer and lighter and of a grayish colour approaching to black. Viewed through the microscope, this powder presented nothing but brilliant particles of pyrites without any trace of sulphur either separate or mingled with the pyrites.

(a.) The solution deposited on being brought into contact witl the air, a yellow ochre; it was then entirely neutral.

I treated this solution with nitric acid in order to oxidate the excess of iron, and I afterwards decomposed it by means of muriate of barytes and caustic ammonia. The product was $2.03 \mathrm{gr}$. of sulphate of barytes; and after separating the ex-

* From the Alnales de Chimie for April 1822.

Fol. 60. No. 291. July 1822. 
cess of muriate of barytes by sulphuric acid, $0.68 \mathrm{gr}$. of peroxide of iron, the proportions were exactly the same as the neutral sulphate of protoxide of iron $\left(\mathrm{Fe} \mathrm{S}^{2}\right)$ would have given; for $29.16: 9.78=2.03: 6.809$

The salt formed was equal to 0.74 gr. of proto-sulphuret of iron $(\mathrm{Fe} \mathrm{S})$; but the residue of the pyrites not decomposed, weighed $4.653 \mathrm{gr}$; that is to say, six and seven times as much as the effloresced part.

(b.) To make sure that the undissolved residue did not contain any free sulphur, I dissolved some of the loosest of it by means of nitro-muriatic acid, until there was an entire acidification of the sulphur. 'There remained a little silex not dissolved. The solution furnished $0.64 \mathrm{gr}$. of oxide of iron and $3.82 \mathrm{gr}$. of sulphate of barytes, which perfectly accords with the composition of dento-sulphuret of iron, that is to say, pyrites. Since therefore the effloresced part was a sulphate, with a protoxide for its base which did not contain any excess of acid, and since there were no traces of sulphur being separated during the efflorescence, it is evident that the effloresced part must have been a proto-sulphuret of iron, $\mathrm{Fe} \mathrm{S}^{3}$, which has not yet been found in an isolated state in the mineral kingdom*, and that the remainder, which was not liable to effloresce, had been a deuto-sulphuret, $\mathrm{Fe} \mathrm{S}^{*}$.

The efflorescent pyrites cannot therefore be any thing else than particles more or less crystallized of $\mathrm{Fe} \mathrm{S}^{2}$, cemented together by particles more or less numerous of $\mathrm{Fe} \mathrm{S}^{2}$, which convert themselves by little and little, by exposure to the air, into $\mathrm{Fe} \mathrm{S}$; the pyrites loses then its coherence in proportion as the cement of the crystallized particles is destroyed.

The efflorescence does not therefore furnish any che to the solution of the question as to the difference between the forms of yellow and white pyrites.

* It will be recollected that the magnetic pyrites which does not effloresce is a chemical combination of $\mathrm{Fe} \mathrm{S}+6 \mathrm{FeS}$ :

\section{Notices respecting New Books.}

Sciography, or Examples of Shadows, and Rules for their Projection, intended for the Use of Architectural Draughtsmon; by Joseph Gwilt, Architect. 8vo. 9s.

Practical Hints on Composition in Painting; illustrated by Examples from the Great Masters of the Italian, Flemish, and Dutch Schools; by John Burnet. 4to. 12s.

An Encyclopedia of Gardening; comprising the Theory and Practice of Horticulture, Fioriculture, Arboriculture, and 